\title{
Transatlantica
}

Revue d'études américaines. American Studies Journal

Cartographies de l'Amérique / Histoires d'esclaves

\section{Rosa Parks @ 100}

An interview of Riché Richardson

\section{Géraldine Chouard et Anne Crémieux}

\section{(2) OpenEdition}

Journals

Édition électronique

URL : https://journals.openedition.org/transatlantica/6067

DOI : 10.4000/transatlantica.6067

ISSN : $1765-2766$

Éditeur

Association française d'Etudes Américaines (AFEA)

Référence électronique

Géraldine Chouard et Anne Crémieux, «Rosa Parks @ 100 »,Transatlantica [En ligne], 2 | 2012, mis en ligne le 20 août 2013, consulté le 06 avril 2023. URL : http://journals.openedition.org/transatlantica/ 6067 ; DOI : https://doi.org/10.4000/transatlantica.6067

Ce document a été généré automatiquement le 6 April 2023

\section{(c) $($ () $\ominus$}

Creative Commons - Attribution - Pas d'Utilisation Commerciale - Pas de Modification 4.0 International - CC BY-NC-ND 4.0

https://creativecommons.org/licenses/by-nc-nd/4.0/ 


\title{
Rosa Parks @ 100
}

\author{
An interview of Riché Richardson
}

\section{Géraldine Chouard et Anne Crémieux}

Cornell University associate professor Riché Richardson, a native of Montgomery, Alabama, gave a talk at the Rosa Parks Museum in the city on February 4, 2013 entitled "Rosa Parks @100" as part of the national celebration from Montgomery to Detroit. Her art quilt, "Rosa Parks, Whose 'No' in 1955 Launched the Montgomery Bus Boycott and Was Heard Around the World," is among the art that was presented at this historic celebration. Other highlights included National Book Award poet Nikky Finney reading "Red Velvet," the presentation of the Rosa Parks 100th Birthday Wishes" project by museum Director Georgette Norman and curator Daniel Niel, and the presentation of a new commemorative U.S. Postage stamp honoring Rosa Parks. In the light of these events, here are a few questions for the artist :

GC \& AC : Why did you dedicate this new quilt to Rosa Parks? Was it commissioned?

RR : In part because I was born and raised in Montgomery, Alabama, which is known as the birthplace of the Civil Rights Movement, I've been continually committed to thinking and learning about civil rights history. I initially designed a Rosa Parks art quilt for my first exhibition held at the Rosa Parks Museum, and had begun this project when I was still living in California. My goal had been to continue work on the quilt when I returned from my first Paris trip in the summer of 2007, but radial nerve damage in my hand slowed down the work. I put it aside with the goal of including it in my next show. After several years of work, I finally completed the Rosa Parks quilt in the months leading up to her $100^{\text {th }}$ birthday. I decided to release a print card in honor of the celebration. No, I haven't done a commission as yet. 


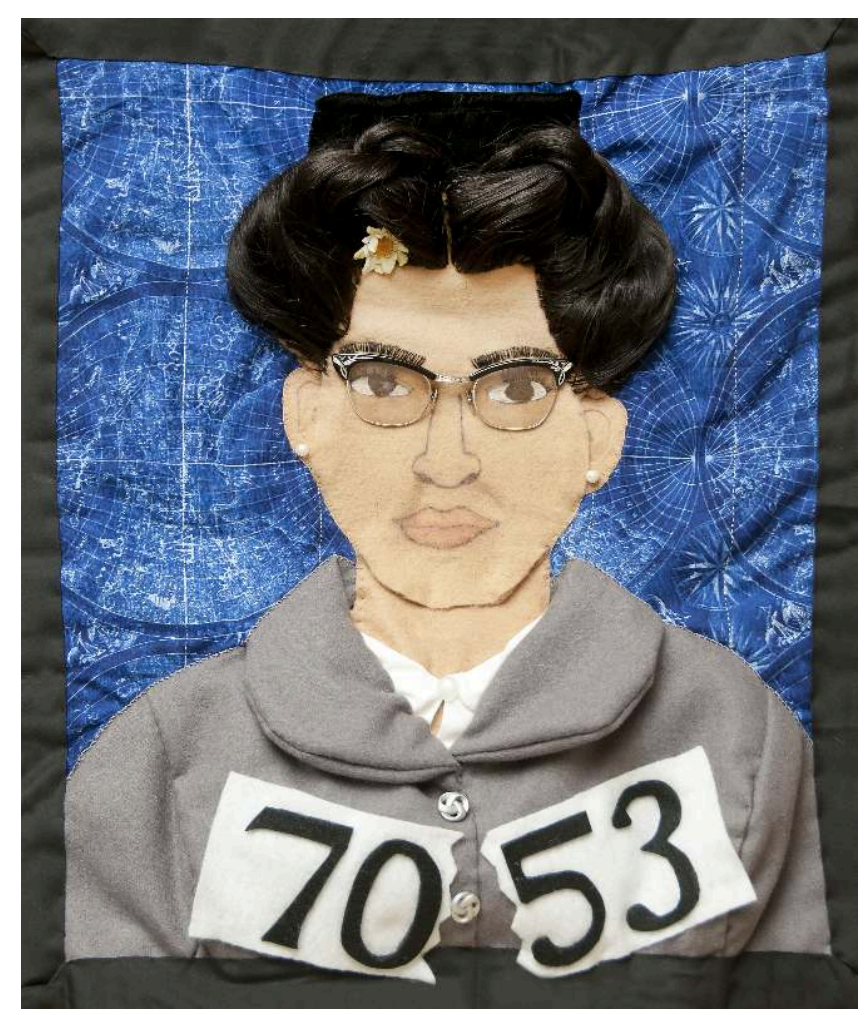

Fig \# 1."Rosa Parks, Whose 'No' in 1955 Launched the Montgomery Bus Boycott and Was Heard Around the World"( Commemorating 100 Years, 1913-2013) (Civil Rights Movement Series, Black History Series, \& Alabama Women Series). Donation to the permanent collection of Troy University's Rosa Parks Museum, Montgomery, Alabama. From upcoming solo exhibition entitled "Portraits II : From Montgomery to Paris"(2015). Dedicated to Georgette Norman, Director of the Rosa Parks Museum in Montgomery, AL.

GC \& AC : How does this quilt figure into your past works of iconic figures, such as Martin Luther King (2004), Malcolm X (2004) and Obama (2009)? In particular, how does it compare with your quilts commemorating other women, like Josephine Baker (2005), Simone de Beauvoir (2007) and Toni Morrison (2010)?

RR : I think that this quilt of Rosa Parks builds upon my commitment to exploring a diverse range of political and cultural figures. There is some overlap with the King, Malcolm X and Obama quilts included within my ongoing "Political Series." The Malcolm X quilt is the first one that incorporated antique eyeglasses as a feature and so established some of the groundwork in design for the Rosa Parks quilt. Furthermore, this quilt is the only one besides the one featuring President Obama that has been introduced on a Special Edition Print Card. Like the Toni Morrison quilt, it attempts to visually teach about an important contributor to both black and women's history. All of the quilts that I have done of women reinterpret iconic images or photos. In the case of Simone de Beauvoir, I focused on the cover of her first memoir. In the case of Toni Morrison, I was interpreting a Time magazine cover. In the case of Rosa Parks, I reinterpret her famous arrest photo.

GC \& AC: You chose to reproduce Rosa Park's famous 1955 mug shot, with some differences. What is the significance of those differences?

$\mathrm{RR}$ : The quilt both repeats and recreates the original image of her arrest photo with some subtle yet crucial differences. The backdrop is not the monochromatic background of the original photo, but an old world map replete with ships to evoke symbolically the action of Rosa Parks as a key moment in the history of the modern 
world, and against the backdrop of modernity, including slavery and the TransAtlantic slave trade. The torn apart arrest number alludes to breaking free. It illustrates how she helped to bring about a new kind of freedom in the twentieth century from the barriers of segregation and Jim Crow. The image also emphasizes her dignity, her beauty, her seriousness, her determination.

GC \& AC : Since the original is in black and white, what was your inspiration for the choice of colors, the background fabric, etc. ?

RR : At first, I was going to use a 1950s world map, but realized that it would be more compelling, and in a sense, more meaningful, to evoke Rosa Parks in relation to a much longer and larger historical narrative spanning back several centuries. A number of precursors also paved the way to her act of resistance, including figures such as Ida B. Wells, who challenged Jim Crow on the railroad's cars in a lawsuit in 1884. The blue map fabric evokes Rosa Parks's famous action within the long history of modernity. At the same time, it signals her continuing global reach and impact. The quilt's rainbow back reminds us of how much she is embraced by diverse cultures. When we talk about Parks, it is useful to think of this history, and also, to imagine futurity, or the generations who will continue to learn about and carry on her important legacy as time goes on.

GC \& AC: Is the quilt on display somewhere? Who sees it? What kind of reactions have you heard, if any?

RR : I had the honor of presenting a talk entitled "Rosa Parks @ 100" at the landmark celebration of Rosa Parks's centennial birthday in Montgomery on a rich program developed by Later that night, I also unveiled the quilt and donated it to the museum's permanent collection, where it will be installed soon. It will also offer the public a preview of my new quilt show scheduled for 2015. It got wonderful reactions the night that I shared it publicly for the first time. A set of 1000 print cards was made to coincide with her national birthday celebration. Some people who have received cards are framing them. This was a special way to share a piece of Rosa Parks art and small keepsake in various communities, including Montgomery, my hometown and Mrs. Parks's, and to help underscore the continuing significance of her famous choice to remain seated on the bus in 1955.

GC \& AC : What did you think of Rosa Parks' $100^{\text {th }}$ birthday celebration, and, in particular, the unveiling of the new stamp?

RR : The new Rosa Parks postage stamp is an important milestone. In my research, I am interested in thinking about how Rosa Parks has impacted notions of national femininity and emerged as an emblem of the national body. I am also inspired that so many people with diverse perspectives in our culture, and even politicians from liberal to conservative, including U.S. presidents such as Bill Clinton, George W. Bush, and Barack Obama, all value and embrace her legacy. Just as she was a person of profound religious faith, she deeply believed in democracy. It is also significant that she is the first black person to be represented in a life-size statue in Statuary Hall in the nation's capitol building. This new statue affirms the continuing significance of Rosa Parks and the Montgomery Bus Boycott for all Americans, as well as for people around the globe. It opens the door to new teaching opportunities related to her important legacy. 


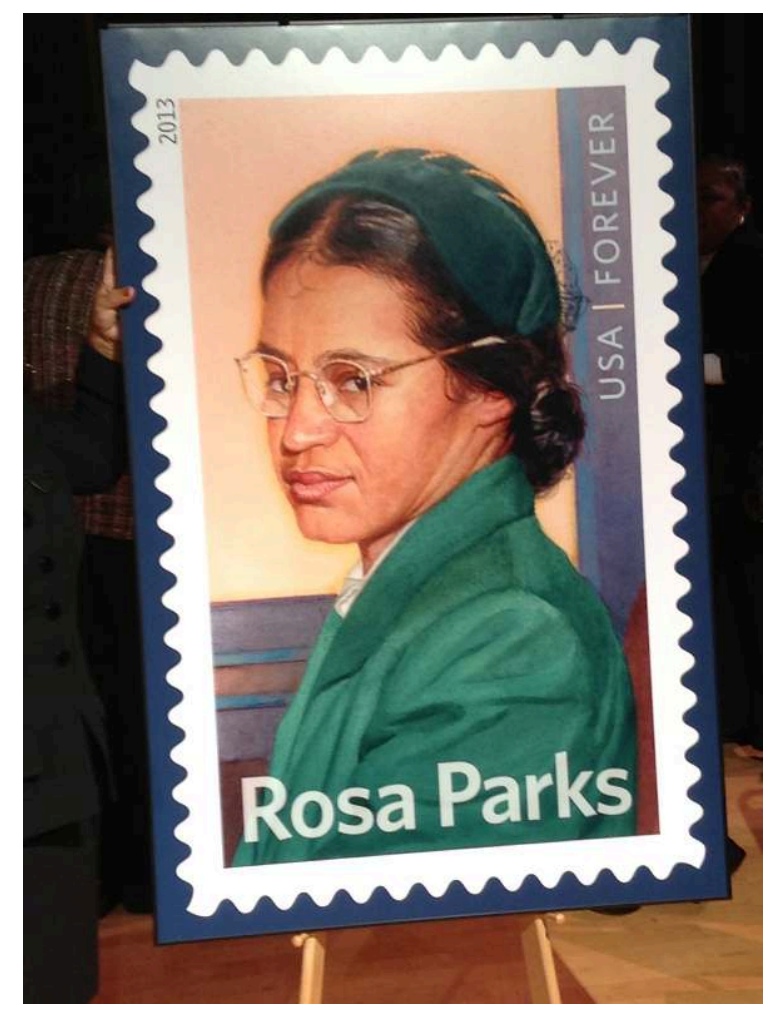

Fig \# 2 : Rosa Parks Stamp, released on February $4^{\text {th }}, 2013$

\section{GC \& AC : What do you think of the "forever" stamp series?}

$\mathrm{RR}$ : The release of the stamp at the major celebrations of her legacy in honor of her $100^{\text {th }}$ birthday was truly special. It was a deep honor to be invited by Montgomery Postmaster Donald Snipes to participate in the stamp unveiling at her birthday celebration in Montgomery, on top of presenting a talk and quilt in her honor. of course it is also important to recognize that the enshrinement of a subversive figure such as Rosa Parks on a postage stamp at the national level easily risks appropriating her legacy and obscuring how imperiled she once was in the face of state power. In 1999, the release of a U.S. postage stamp in honor of Malcolm X, for example, seemed somewhat ironic. However, I think most importantly, the stamp can be read as a barometer of how much African Americans such as Mrs. Parks have shaped visions of freedom and democracy in the U.S.

GC \& AC : What does Rosa Parks mean for Americans today?

RR : Rosa Parks embodies the spirit of democracy and when she sat down, she moved democracy forward. Her earliest work centered on youth as she worked with the NAACP Youth Council, and mentored youth such as Mary Frances Whitt prior to her arrest in 1955. Rosa Parks was also tireless as an activist committed to helping children gain access to segregated libraries. Children were at the very heart of Rosa Parks's lifelong mission. Indeed, the 'Rosa Parks $100^{\text {th }}$ Birthday Wishes" project at Rosa Parks Museum in Montgomery is one of the best possible tributes to her that could have been envisioned to help celebrate this important moment; this is a project that has been extended until November 18 and that youth everywhere are urged to get involved with, by sending their wishes (i.e. for their city, their nation, the world) in a sentence or two to Georgette Norman at gmnorman@troy.edu. To this 
day, her example brings hope and inspiration to people everywhere, including many children.

\section{GC \& AC : What does it mean to you that Rosa Parks was a quilter ?}

RR: I think that her background as a quilter grounds her in one of the most important and time-honored craft traditions historically embraced and practiced by women, including its manifestations among black women in the United States. Her work as a seamstress was known to be absolutely pristine. Much of this work was done for the public, including customers at the Montgomery Fair department store where she was working in Montgomery at the time of her arrest. Awareness of her interest in quilting is a further indication of her thoroughgoing commitment to the practice of sewing, and provides a compelling example of how her handiwork also enhanced and beautified her life and her home. In your 2008 film A Portrait of the Artist, I appreciate that Pat Turner emphasizes the background of Rosa Parks as a quilter.

GC \& AC : What are your next quilting projects ? Are you going to contribute in some way to the $50^{\text {th }}$ anniversary of the Freedom Rides in 2015 ? If so, how?

$\mathrm{RR}$ : The major art initiative that we are planning for 2015 is very much communitybased and will unfold against the backdrop of events such as the $50^{\text {th }}$ anniversary of the Selma-to-Montgomery March and the Voting Rights Act of 1965 , and the $60^{\text {th }}$ anniversary of the beginning of the Montgomery Bus Boycott in this important jubilee year. My Civil Rights Movement Series featuring Mrs. Parks, Johnnie Rebecca Carr and E.D. Nixon, some of the major figures associated with the Montgomery Bus Boycott, will help mark this important time. It will also be important to think about the sesquicentennial of 1865 in terms of what it meant for slavery and the long history of black freedom struggle. As some may recall, 2015 will also mark the $50^{\text {th }}$ anniversary of the loss of Malcolm X. My art quilt exhibition was in place in Montgomery during the summer of 2008 on the $40^{\text {th }}$ anniversary of the losses of Dr. King and Robert Kennedy; the film A Portrait of the Artist also mentions all of these tragedies. To take another example, I exhibited in Paris and then Washington DC as part of the backdrop for Obama's Inauguration celebrations. The movements of my art at these levels have occurred in the public sphere and have been designed to help promote education through art, as well as principles of democracy and civility.

GC \& AC : Is there anything else you would add?

RR : When I was 17, I wrote a poem honoring Rosa Parks entitled "Together We Will Win" during a period when I was also working in Montgomery with youth as a volunteer at the Cleveland Avenue YMCA, right down the street from where Mrs. Parks lived at the time of her arrest. At the time, I was a senior at St. Jude Educational Institute in Montgomery, whose campus is best historically known as the final camping place for Selma-to-Montgomery marchers in 1965. I am just thankful to be able to honor Rosa Parks in new ways at this point in my life, and incidentally, as I also near the age of Mrs. Parks when she was arrested.

GC \& AC: Thank you very much.

RR : Thank you.

Related Links :

http://trojan.troy.edu/community/rosa-parks-museum/birthday-wishes-project.html 
http://www.montgomeryadvertiser.com/article/20130205/NEWS01/302050007

http://www.ithaca.com/news/article_23b89c68-7020-11e2-a717-001a4bcf887a.htmlhttp:// www.news.cornell.edu/stories/Feb13/RichardsonRosaParks.html

http://www.youtube.com/watch?v=7evb7pMFiGw

http://www.youtube.com/watch?v=NB7xICpjxv4

http://www.youtube.com/watch?v=JRLpJpjFbuY

\section{AUTEURS}

\section{GÉRALDINE CHOUARD}

University Paris-Dauphine

ANNE CRÉMIEUX

University Paris-Ouest Nanterre 